\title{
Fungal sporulation in a Permian plant fragment from Antarctica
}

\author{
CARLA J. HARPER, Edith L. TAYLOR, ChRISTOPHER WALKER, JAMES F. White, \\ RUDOLPH SERBET \& MICHAEL KRINGS
}

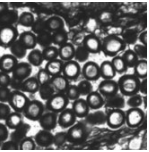

Documented evidence of fungi from the Permian of Antarctica mostly consists of dispersed remains that do not provide the whole complement of diagnostic features necessary to determine even broad systematic affinities. A dense cluster of $>250$ fungal spores occurs within a degraded vascular plant (probably glossopteridalean) fragment in Permian permineralized peat from Skaar Ridge, central Transantarctic Mountains, Antarctica. Spores are spheroidal to ovoid, $\sim 50 \mu \mathrm{m}$ in diameter, and possess a massive wall composed of three wall components (wc1-3); one or two canals extend from the spore lumen to the outside. The spores are embedded in a confluent meshwork of tenuous hyphae. Structural similarities exist between the fossil spores and spores produced by certain present-day Mucoromycota, Ascomycota, and Basidiomycota; however, the precise systematic affinities of the fossils cannot be determined. The relationship between the spore producer and its also host plant remains unresolved. Nevertheless, the spatial arrangement of the spores within the plant structure suggests that the fungus required the host for sporulation, and perhaps even influenced plant development for this purpose. This discovery adds to the inventory of distinctive fungal fossils from the Permian of Antarctica and presents a new type of association/interaction between a Permian fungus and a vascular plant. $\bullet$ Key words: development, interaction, Glossopteris, parasitism, saprotrophism, spore wall.

Harper, C.J., TAylor, E.L., Walker, C., White, J.F., Serbet, R. \& Krings, M. 2018. Fungal sporulation in a Permian plant fragment from Antarctica. Bulletin of Geosciences 93(1), 13-26 (4 figures). Czech Geological Survey, Prague. ISSN 1214-1119. Manuscript received June 7, 2017; accepted in revised form October 27, 2017; published online March 29, 2018; issued March 31, 2018.

Carla J. Harper \& Michael Krings, Department für Geo- und Umweltwissenschaften, Paläontologie und Geobiologie, Ludwig-Maximilians-Universität, and Bayerische Staatssammlung für Paläontologie und Geologie, Richard-Wagner-Straße 10,80333 Munich, Germany; c.harper@lrz.uni-muenchen.de, m.krings@lrz.uni-muenchen.de • Edith L. Taylor, Carla J. Harper \& Michael Krings, Department of Ecology and Evolutionary Biology, and Biodiversity Institute, University of Kansas, Lawrence, KS 66045-7534,USA; charper@ku.edu, etaylor@ku.edu・Christopher Walker, Royal Botanic Garden Edinburgh, 20A Inverleith Row, Edinburgh EH3 5LR, UK \& School of Agriculture and Environment, University of Western Australia, 35 Stirling Highway, Crawley,WA 6009, Australia; C.Walker@rbge.org.uk • James F. White, Department of Plant Biology, Rutgers University, New Brunswick, NJ 08901, USA; james.f.white@rutgers.edu • Rudolph Serbet, Division of Paleobotany, Biodiversity Institute, University of Kansas, Lawrence, KS 66045-7534,USA; serbet@ku.edu

Structurally preserved fossils of fungi from Antarctica have to date primarily come from Triassic permineralized peat, while the record from comparable Permian-aged peat deposits remains meager. This is in spite of the fact that the Antarctic Permian deposits have yielded a number of structurally preserved plant fossils, including a moss, lycopsids, a fern, and several different seed plants (Smoot \& Taylor 1986; Galtier \& Taylor 1994; McLoughlin \& Drinnan 1996; Slater et al. 2011; Ryberg et al. 2012a, b; McLoughlin et al. 2015). The vast majority (> $80 \%$ of specimens in some localities; Cúneo et al. 1993) of plant remains preserved in the Permian peat are disarticulated parts of glos- sopterid seed ferns (e.g., Schopf 1970a, b, 1976; Smoot \& Taylor 1986; Taylor \& Taylor 1987, 1992; Klavins et al. 2001; Taylor et al. 2007; Ryberg 2009, 2010; Ryberg et al. 2012a; Ryberg \& Taylor 2013).

The documented record of fungi from Permian peat deposits almost exclusively consists of dispersed and fragmentary remains (Holdgate et al. 2005; García Massini 2007; Harper et al. 2015, 2016; Slater et al. 2015), with little information available on the biology and ecology of the fungi. Permian Antarctic fungal interactions are documented almost exclusively with members of the Glossopteridales, with one notable exception with 
lycopsids (McLoughlin et al. 2015), and include mycorrhizal associations with young Vertebraria rootlets, wood decay fungi, fungal hyphae and reproductive units associated with Glossopteris leaves, and fungi colonizing coprolitic material from inside excavated galleries in glossopterid structures (Weaver et al. 1997; McLoughlin et al. 2011; Slater et al. 2012, 2015; Harper et al. 2013, 2015, 2017a). Fungi have also been reported in association with glossopterid pollen within sporangia (Slater et al. 2015) from Antarctica; however, to date there are no studies that exclusively focus on fungi associated with glossopterid reproductive structures.

In this study we present a detailed account of an interesting fungus associated with a partially degraded, putative glossopterid plant fragment from the Permian permineralized peats from Skaar Ridge, central Transantarctic Mountains of Antarctica. The fungus occurs in the form of spheroidal spores with massive walls that are embedded in a confluent mycelium in the head-like, distal portion of the plant fragment. Especially interesting is the large number of spores $(>250)$ comprising the cluster. This discovery adds to the inventory of distinctive fungal fossils from the Permian of Antarctica and presents a new type of association/interaction of a Permian fungus with a vascular plant.

\section{Geologic setting, materials, and methods}

The fossil comes from a permineralized peat that occurs at

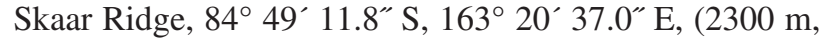
$8600 \mathrm{ft}$ ), located within the Buckley Formation near the Beardmore Glacier Area, Queen Alexandra Range, central Transantarctic Mountains, Antarctica. The Buckley Formation has been dated as upper Permian (260-251.9 Ma) based on palynological data (Farabee et al. 1990, 1991; Collinson et al. 2006) that correlates to the Australian APP5-APT1 biozones (Price et al. 1985, Mantle et al. 2010). The formation consists of coal measures at least $745 \mathrm{~m}$ thick that crop out extensively throughout the central Transantarctic Mountains (Barrett et al. 1986). The coal measures are informally subdivided into two members: (1) a lower, arkosic sandstone with at least $25 \%$ feldspar and (2) an upper, volcanoclastic member (Barrett et al. 1986, Isbell 1990, Collinson et al. 1994). The deposits from the lower member include permineralized (silicized) peat that is rich in anatomically preserved plant fossils, including Glossopteris leaves, wood traditionally assigned to
Australoxylon (Decombeix et al. 2009, 2010), several seed plant reproductive structures (Taylor et al. 1989, Cúneo et al. 1993, Ryberg 2009, Ryberg et al. 2012a), and Vertebraria-type roots (Decombeix et al. 2009), as well as various types of microorganisms (see references in Harper et al. 2016).

The peat block (16143 F1 bot) containing the fungus was cut into slabs with an oil-cooled lapidary saw and then individual slabs were immersed in hydrofluoric acid (conc. $48 \%$ ) to dissolve the silica. Acetate peels were subsequently produced from the etched surfaces using the acetate peel technique (Joy et al. 1956) modified for hydrofluoric acid (Galtier \& Phillips 1999) and then screened for fossilized fungal remains. Consecutive peels of the specimen used in this study were mounted on microscope slides with Eukitt ${ }^{\circledR}$ mounting medium (O. Kindler, Freiburg, Germany). The fossil was further prepared by making a single thin section. A slice of the peat was cemented with UV-cured epoxy to a glass slide and then ground thin enough to view with transmitted light. The mounted peels and thin section were analyzed using a Leica DM LB2 transmitted light microscope; digital images were captured with a Leica DFC-480 camera and processed in Adobe Photoshop CS5. When suitable specimens were identified, they were processed minimally (i.e., contrast, brightness, and focal stacking) and measurements were taken using Adobe Photoshop CS6 Version $13.0 \times 64$ (C1990-2012, Adobe Systems). When necessary, multiple images of the same specimen were recorded at different focal planes and compiled to produce composite images. The images were stacked in Adobe Photoshop CS6 and specific areas were modified to reveal the complete three-dimensional image as seen in the thin section. Composite images in this study are Figs 1A-E, 2B-E, L, N, P, and Q. The specimen and slides are deposited in the Paleobotanical Collections, Biodiversity Institute, University of Kansas (KUPB) under specimen accession number KUPB 16,143 F1 bot and slide accession numbers KUPB 30,262-30,265.

\section{Results}

\section{Surrounding matrix and morphology of the host (Figs 1A-E, 2A)}

The fungal remains occur within a detached, partially degraded vascular plant structure that is $1.96 \mathrm{~mm}$ wide

Figure 1. Fungal sporulation in Permian plant structure - the host. $\bullet A-$ overview of host plant structure. Scale bar $=1 \mathrm{~mm}$. $\bullet \mathrm{B}-$ higher magnification of structure in Fig. 1A, stratified layer (str), fungal spores (s), parenchyma cells (pc), xylem (x), and stalk (stl). Scale bar $=500 \mu \mathrm{m}$. $\bullet \mathrm{C}-$ higher magnification of lower box (1) in Fig. 1A, showing tracheids (x) in stalk. Scale bar $=50 \mu \mathrm{m} . \bullet \mathrm{D}$ - higher magnification of tracheids with scalariform thickenings (arrowheads) in Fig. 1C. Scale bar $=10 \mu \mathrm{m}$. $\bullet \mathrm{E}$ - overview and higher magnification of region in upper box (2) in Fig. 1A, showing head of host structure colonized by fungal spores. Scale bar $=500 \mu \mathrm{m}$. 


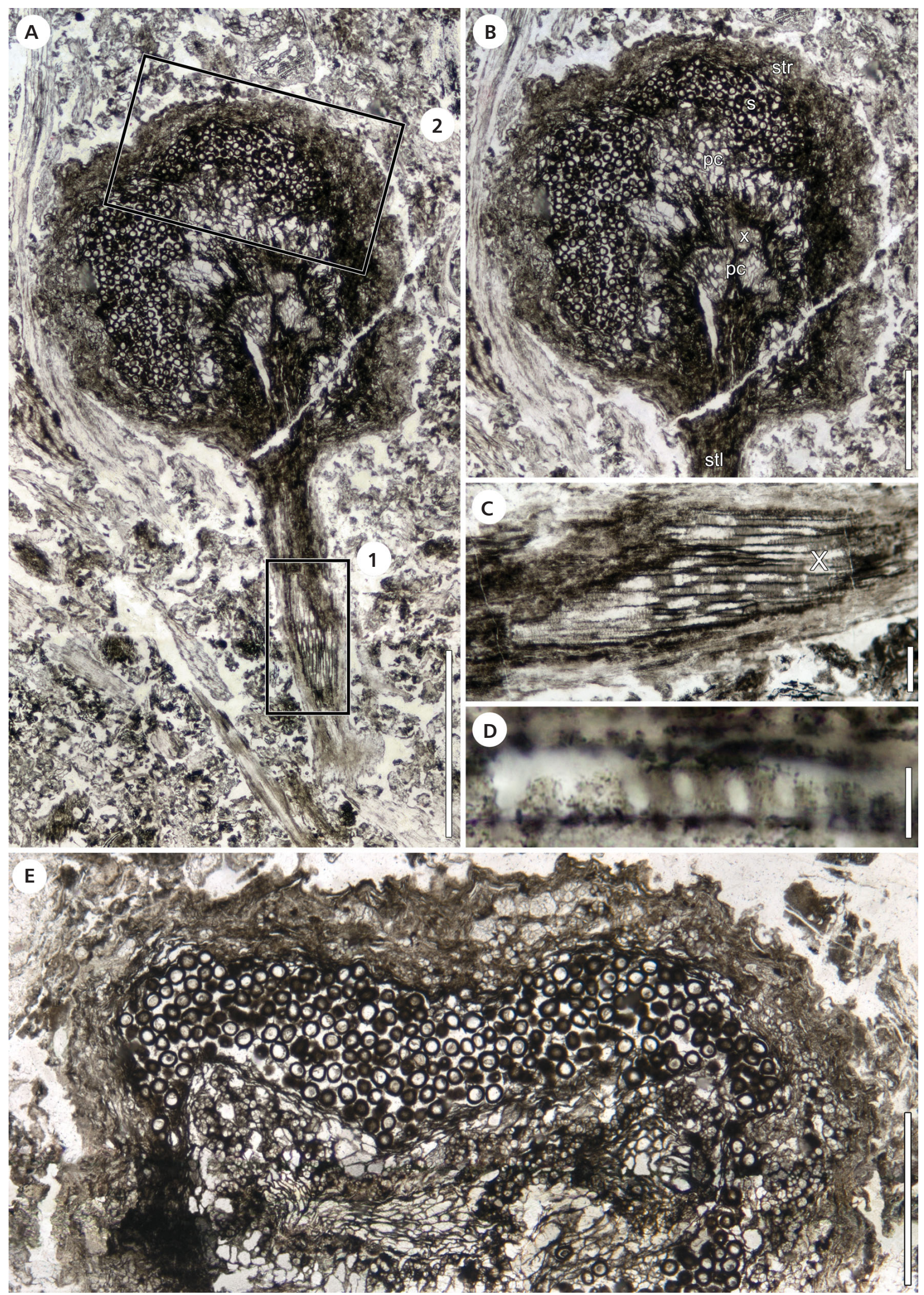


and $3.71 \mathrm{~mm}$ long. The structure is composed of an enlarged distal portion (henceforth 'head') $1.96 \mathrm{~mm}$ wide and $1.92 \mathrm{~mm}$ long, and a proximal, narrow stalk (denoted 'stl' in Fig. 1B), $0.34 \mathrm{~mm}$ wide and $1.79 \mathrm{~mm}$ long. The host structure co-occurs in the peat matrix with abundant young Vertebraria rootlets in different stages of decomposition, woody axes, peronosporomycete oogonia, coprolites, poorly preserved, unidentifiable plant fragments and other organic matter, as well as sediment particles.

All tissues of the host structure are heavily degraded, rendering it impossible to determine internal organization. The outer surface of the head occurs in the form of a narrow, prominently undulate to irregularly wrinkled, opaque layer up to $60 \mu \mathrm{m}$ thick (Fig. 1B). The zone extending along the inside of the surface layer ('str' in Fig. 1B) is characterized by a faint, irregular stratification and probably represents (part of) the cortex. The stratified zone is up to $165 \mu \mathrm{m}$ wide in some areas, but on average 50-70 $\mu \mathrm{m}$ thick. Peculiar muriform structures, ranging from 6-10 $\mu \mathrm{m}$ in diameter, are scattered throughout this zone. Muriform structures are highly variable in size and shape, and display various combinations of transverse and/or longitudinal partitions resulting in the formation of 2 to 6 compartments. Two to several muriform structures together may form small groups that are 15-20 $\mu \mathrm{m}$ in diameter (lower bracket in Fig. 2A) or larger clusters 60-80 $\mu \mathrm{m}$ in diameter (upper bracket in Fig. 2A). Beneath the stratified zone is a large, more or less hemispherical void ( $1950 \mu \mathrm{m}$ wide and $500 \mu \mathrm{m}$ high) that is filled with fungal spores and mycelium (see Fungi section below). The central portion of the head is dome-shaped and consists of what appear to be poorly preserved parenchyma cells ('pc' in Fig. 1B) $30 \mu \mathrm{m}$ in diameter and tracheids (' $\mathrm{x}$ ' in Fig. 1B) that extend from the stalk into the head. The tissues of the stalk are poorly preserved and individual elements are almost indistinguishable from one another. However, one oblique section (Box 1 in Fig. 1A) reveals that a strand of tracheids (Fig. 1C) (12-15 $\mu \mathrm{m}$ individual tracheid width) with scalariform thickenings occurs in the center of the stalk (arrowheads in Fig. 1D).

\section{Fungi (Fig. 2B-S)}

Spores. - The central void in the head of the plant fragment is completely filled with fungal remains in the form of spores and mycelia (Figs 1E, 2F). Spores are spheroidal, prolate, or ellipsoidal, with an average diameter (for globose specimens) of $52 \mu \mathrm{m}(\mathrm{n}=100)$, and constructed of a massive, stratified wall surrounding a central lumen (Fig. 2G; see Fig. 3A for a graphic depiction of spore morphology). The spore wall is comprised of three distinct wall components [see Fig. 3B for a graphic depiction of spore wall architecture (murograph)]; however, not all wall components are discernible in all spores, due primarily to the opacity of the specimens. The outer wall component (wc1) is a narrow (1.7-2 $\mu \mathrm{m}$ thick), irregular, perhaps ephemeral sheath (Fig. 2G). Some spores that are directly adjacent to each other appear to possess an additional, distinct boundary layer that develops between the abutting outer spore wall components (Fig. 2H, I). Wall component 2 (wc2) is the most prominent element of the spore wall (Fig. 2J), and is on average $9.4 \mu \mathrm{m}$ thick $(n=100)$. Radial and transverse sections of wc2 show radial striations that are regularly arranged and extend the entire width of the component (arrowheads in Fig. 2K). However, surface views and tangential sections indicate that the striations in fact represent columns or spines (on average $1 \mu \mathrm{m}$ wide) extending through wc2. The outer surface of the spores therefore often appears "dotted" (Fig. 2L). Spore wall component 3 (wc3) is up to $6 \mu \mathrm{m}$ thick (Fig. 2M). Nevertheless, some of the wall component dimensions might not be natural features, but rather preservation artifacts caused by shrinkage or swelling during fossilization (see Krings \& Taylor 2015), or post-mortem shrinkage prior to fossilization. The spore lumen is usually filled with amorphous matter (Fig. 2D, O), but may also be empty (Fig. 2M), or contain one to several spherical inclusions (Fig. 2N).

Approximately $27 \%$ of the spores show a single, prominent canal, 8.1-8.7 $\mu \mathrm{m}$ in diameter and 6.6-6.9 $\mu \mathrm{m}$ deep, that appears to extend through all three spore wall components (Fig. 2O), while $3 \%$ of specimens possess two canals at opposite poles (Fig. 2P). The lack of canals in the remaining $70 \%$ of spores might be a natural feature or simply

Figure 2. Fungal sporulation in Permian plant structure - the fungus. $\bullet$ A - faintly stratified zone of head containing large (top white bracket area) and medium-sized muriform clusters (lower white bracket area). Scale bar $=100 \mu \mathrm{m} . \bullet \mathrm{B}-$ thick-walled spores $(\mathrm{S})$ and dark hyphae (arrow) attached to spore. Scale bar $=10 \mu \mathrm{m}$. $\bullet \mathrm{C}$ - high magnification of septate (white arrow) hyphae and attachment to outer spore wall component wc1 (black arrow). Scale bar $=10 \mu \mathrm{m}$. $\bullet \mathrm{D}$ - thick-walled spore attached to thick hyphae (white arrow) and blunt hyphal attachment point (black arrow) on spore wall component wc1. Scale bar $=10 \mu \mathrm{m}$. $\bullet \mathrm{E}$ - right-angle branching of septate (arrow) hypha. Scale bar $=10 \mu \mathrm{m}$. $\bullet \mathrm{F}-$ high magnification of several spores. Scale bar $=50 \mu \mathrm{m} . \bullet \mathrm{G}$ - thick-walled spore showing well preserved wall component 1 (1). Scale bar $=10 \mu \mathrm{m}$. $\bullet \mathrm{H}-$ two spores with abutting wall components 1 (wc1), showing formation of separate wall components between spores (arrow). Scale bar $=10 \mu \mathrm{m}$. $\bullet \mathrm{I}-\mathrm{two}$ spores with abutting wall components 1 and indent (arrow) between spores. Scale bar $=10 \mu \mathrm{m}$. $\bullet \mathrm{J}-$ spore wall component $2(2)$ showing radial striations $($ arrow $)$. Scale bar $=10 \mu \mathrm{m}$. $\bullet \mathrm{K}$ - high magnification of striation in spore wall component 2 (wc2). Individual striae bracketed by arrowheads. Scale bar $=10 \mu \mathrm{m}$. $\bullet \mathrm{L}-\mathrm{surface}$ view of two adjacent spores with voids (arrows). Note columns or spines extending from wall component 2 (wc2) in surface view. Scale bar $=10 \mu \mathrm{m}$. 

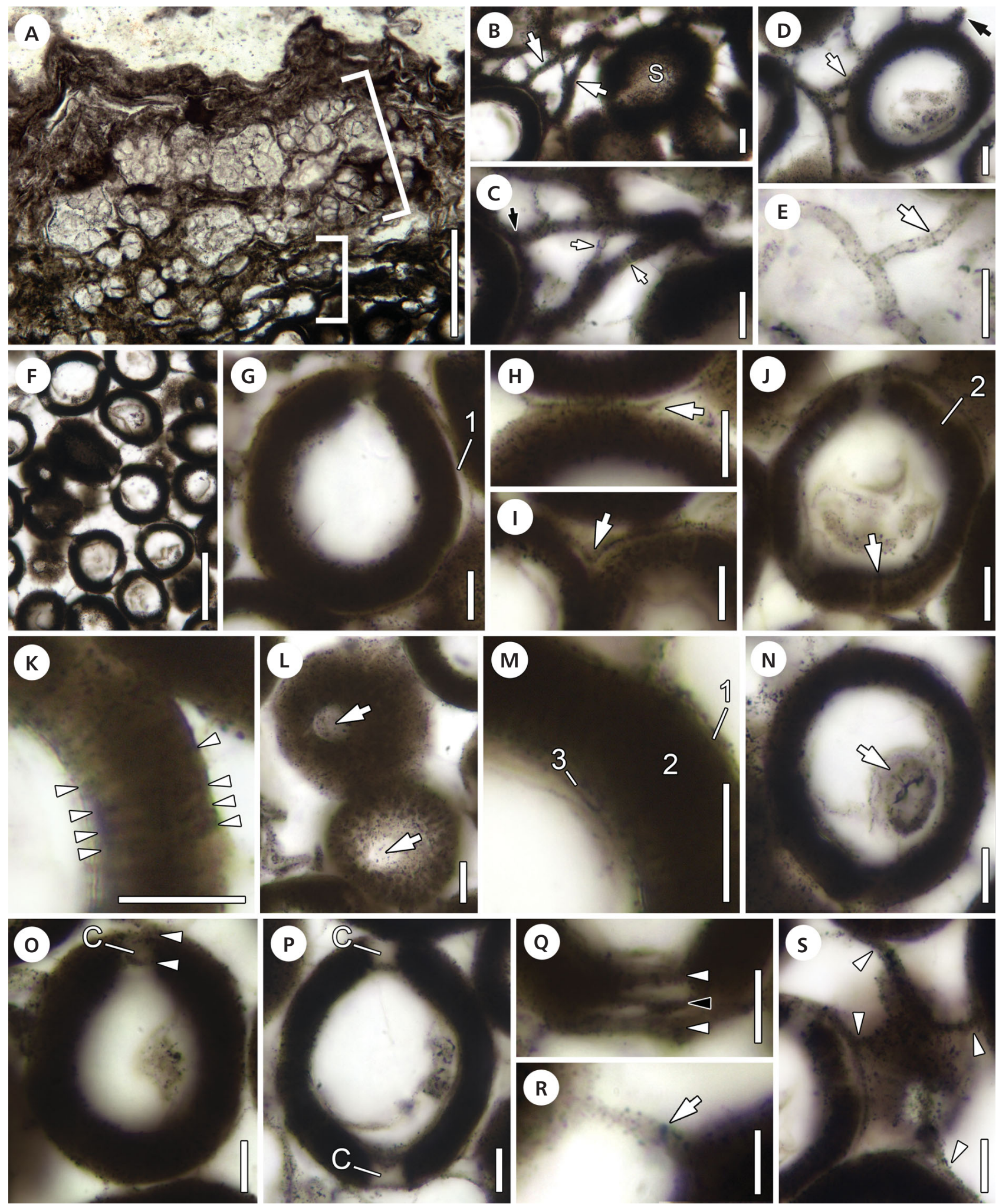

- M - high magnification of spore walls; wall components (wc1-3) denoted. Scale bar $=10 \mu \mathrm{m} . \bullet \mathrm{N}-$ spherical content (arrow) in spore. Scale bar $=10 \mu \mathrm{m}$. $\bullet \mathrm{O}$ - spore with one canal (C). Canal bounded by thin membranes (arrows). Scale bar $=10 \mu \mathrm{m} . \bullet P-$ spore showing two canals (C). Scale bar $=10 \mu \mathrm{m} . \bullet \mathrm{Q}-$ high magnification of canal bounded by thin membranes (white arrows) and middle membrane (black arrow). Scale bar $=10 \mu \mathrm{m}$. - R - hypha with septum (arrow). Scale bar $=5 \mu \mathrm{m}$. $\bullet \mathrm{S}$ - cruciform-branching of hypha attached to four spores (arrowheads). Note hyphae are attached to outer spore wall component 1 . Scale bar $=10 \mu \mathrm{m}$. 


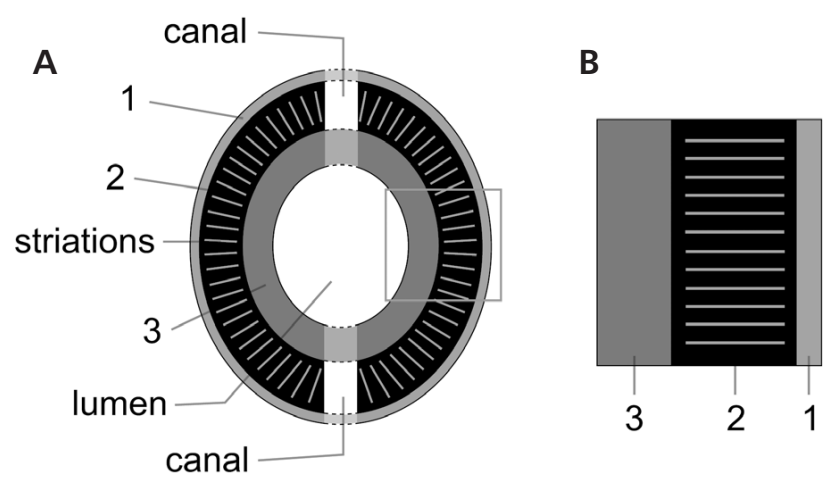

Figure 3. Reconstruction of fungal spore and spore wall components. - A - graphic depiction of spore, showing dimensions and extent of wall components (wc) 1-3, central lumen, and two canals on polar ends. Precise extent of canal unknown due to preservation limitations; spore wall components therefore dashed in region of canal. $\bullet \mathrm{B}$ - spore wall architecture shown in the form of murograph. Style loosely borrowed from murographs in Walker (1983).

result from the plane of section. Transverse sections of spores suggest that a thin membrane occluded the canals (Fig. $2 \mathrm{O}$ arrowheads). There is one specimen that has a single thin membrane in the middle of the canal (Fig. 2Q black arrowhead). No collars or extensions above the outer spore wall surface are present, nor are any of the canals directly connected to hyphae.

Hyphae. - The spores are embedded in a confluent meshwork (mycelium) of narrow hyphae or filaments $(1.5-2.5 \mu \mathrm{m}$ in diameter) that branch at regular intervals and at various angles; septa are present but appear to be generally sparse (Fig. 2R arrow) and are irregularly spaced. Many hyphae appear to arise from, produce, or enter into wc1 (Fig. 2S). Each hypha is usually connected with only one spore; however, cruciform, branch-forming hyphae that are attached to 4 different spores do also occur (Fig. 2S).

An ill-defined, opaque layer that contains wide, septate, multi-branched hyphae $2-8 \mu \mathrm{m}$ wide surrounds the cluster of spores and tenuous mycelium. Some of these hyphae are physically connected with spores from the periphery of the spore cluster (Fig. 2B-D). Other wide hyphae extend deeply into the spore cluster directly from the stratified layer of the host structure and appear to merge with wc1 of individual spores (Fig. 2B, C). Spores that are not located in close proximity to wide hyphae may still show attachment scars with diameters corresponding to the diameter of the wide hyphae (Fig. 2D black arrow). A single fragment of a septate hypha shows right angle branching (Fig. 2E).

\section{Discussion}

Determining synapomorphic characters in fungal fossils that exhibit few morphological features, and assessing the nutritional modes of these organisms represent challenging tasks that are often further compounded by the taphonomic or degradational state in which the fossils occur (Taylor et al. 2015). The plant part containing fungal hyphae and thick-walled spores described in this study occurs in a permineralized peat matrix. Since peat forms through the gradual accumulation and compaction of organic matter over longer periods of time, fossil plants and fungi preserved in permineralized peat are typically fragmented, partially decayed, and sometimes severely marred. Moreover, the Permian permineralized peat deposits of Antarctica appear to have developed in a 3-step process (Schopf 1971, Taylor et al. 1989), through which especially the more fragile structures have probably been altered secondarily. As a result, plant structures and fungal remains preserved in these rocks are particularly difficult to interpret.

\section{The host}

None of the fossil plants that have been reported to date from the Permian of Antarctica are known to produce parts that are morphologically congruent with the host structure. Overall morphology suggests that the host is some type of reproductive structure or part of a complex reproductive organ of a vascular plant. The structure is comprised of a vascularized stalk bearing an enlarged distal portion (head) (Fig. 1A). However, the fossil as a whole is ill preserved. Moreover, no spores, pollen grains, or ovules/seeds have been detected within or in close association with the structure and, as a result, render it difficult to determine affinities and, if it does come from a seed plant, whether it is a male or female reproductive structure. It is possible that the structure lacks evidence of sporangia, pollen sacs, or ovules simply because it was immature at the time of fossilization. Alternatively, it might have been post-mature, perhaps even already shed and lying on the forest floor, with sporangia, pollen sacs, or ovule(s) no longer recognizable. It is also possible that the fungus in some way modified or adversely affected the development of the host structure, perhaps in a similar manner as described for certain extant, plant-colonizing fungi that infect reproductive structures and stimulate gall formation (e.g., Clay 1991, Vujanovic et al. 2000, Ngugi \& Scherm 2006). The muriform structures interspersed throughout the fossil plant structure probably represent preservation artifacts, perhaps consolidated bubbles containing gases resulting from degradation processes (Taylor et al. 1997, Krings \& Taylor 2015).

The vast majority of plant reproductive organs that have been described from Skaar Ridge are glossopteridalean (e.g., Taylor \& Taylor 1992, Ryberg et al. 2012a, Ryberg \& Taylor 2013). Consequently, the host 
structure might also be glossopteridalean. However, the host structure does not resemble any of the permineralized glossopterid ovulate or pollen organs known from Skaar Ridge, i.e., Lonchiphyllum aplospermum Ryberg \& E.L. Taylor, Lakkosia kerasata Ryberg, Eretmonia natalensis Ryberg, E.L. Taylor \& T.N. Taylor, and others not formally named (see Schopf 1970a, b, 1976; Taylor \& Taylor 1992; Taylor et al. 2007; Ryberg et al. 2012a; Ryberg \& Taylor 2013). Nevertheless, it is possible that the host represents a permineralization equivalent of a reproductive structure described from Antarctica based on impression/compression fossils such as Cometia, Scutum, Lidgettoniopsis, Plumsteadia, Arberiella, or Rigbya (Lambrecht et al. 1972, Kyle 1974, Schopf 1976, McLoughlin et al. 1997, Rigby et al. 2001, Retallack et al. 2005, Ryberg 2009, Ryberg et al. 2012c), but this is impossible to know based on the specimen at hand.

Alternatively, the host might be a non-glossopteridalean reproductive structure, such as a sporophyll of lycopsid or a plant type that has not been previously documented from this locality. Non-glossopteridalean plant reproductive structures from Skaar Ridge include sporangia of the fern Skaaripteris minuta Galtier \& T.N. Taylor (Galtier \& Taylor 1994) and sporophylls of the herbaceous lycopsid Collinsonostrobus eggertii Ryberg, E.L. Taylor \& T.N. Taylor (Ryberg et al. 2012b), both of which are morphologically dissimilar to and considerably larger than the structure detailed in this study.

It is also possible that the host structure represents some other plant part (e.g., a root or small twig) that has been physically modified beyond recognition by the fungus (see section Affinities of the fungus, Basidiomycota). For example, the peat matrix contains abundant young Vertebraria rootlets characterized by a central vascular bundle surrounded by an intact parenchymatous cortex lacking lacunae, which are a feature of older roots (Decombeix $e t$ al. 2009). It is possible to envision that the host structure represents a Vertebraria rootlet that has been locally infected by a fungus and greatly enlarged in the course of fungal sporulation.

\section{Fungal spore development}

Depictions of different life history stages and ontogenetic development in fossil fungi remain rare (e.g., Kettunen et al. 2015, Krings et al. 2016, Harper et al. 2017b). This is unfortunate because life history and ontogeny represent important diagnostic features that could be used to assess the systematic affinities and biology of these fossil organisms in the absence of molecular data. Krings et al. (2016) recently analyzed large sample sets ( $>100$ specimens) of the fungal reproductive unit Zwergimyces vestitus (Kidst. \& W.H. Lang) M. Krings \& T.N. Taylor from the Lower
Devonian Rhynie chert, and used structural differences between the specimens to reconstruct ontogenetic development. Development might be used to determine the affinities of the Antarctic spores described in this study. However, all spores in the cluster appear to be mature, and no structural differences indicative of a particular developmental sequence are available.

In the Permian fossil, one peculiar feature of the spores is the presence of one or two prominent canals that extend from the spore lumen through the wall in approximately $30 \%$ of specimens. Based on this feature, together with the overall shape and wall architecture of the spores, we hypothesize that the spores represent chlamydospores, which formed on hyphae, either terminally (one polar canal) or in an intercalary position (two polar canals). Unfortunately, the structure of the parental hypha is unclear and the individual spore wall components are difficult to define precisely, rendering it impossible to determine the exact sequence of stages in spore development. Nevertheless, the initial phase might have involved an undifferentiated parental hypha (Fig. 4A) that begins to inflate, either terminally or in an intercalary position between two septa (Fig. 4B). In extant fungi, septa possess a central canal or pore to allow cytoplasmic streaming between adjacent hyphal compartments (Moore \& McAlear 1962). The cytoplasm then contracts in the inflated region, and a wall component is laid down (Fig. 4C). As more wall material is amassed, new wall components and features such as the columns are produced (Fig. 4D, E). The canals connecting the lumen of the parental hypha with the lumen of the developing spore begin to close, and thus gradually disconnect the spore from the parental hypha (Fig. 4F). Upon maturation of the spore, the parental hypha disintegrates (Fig. 4G).

Arguing against this scenario are numerous spores closely associated with single hyphae that appear to enter into, or extend from, the outer wall component (wc1). We propose four hypotheses for the relationship between the spores and hyphae: (1) The hyphae might be the parental hyphae; however, they are not physically connected with the polar canals of the spores, as postulated in the hypothetical developmental sequence. Wc1 perhaps represents the inflated portion of the parental hypha, rather than a component of the spore wall proper. If this is accurate, then it is plausible that the mature spores after being disconnected from the parental hypha, moved or rotated within the inflation of the hypha, perhaps naturally or as a result of fossilization. (2) It is also possible that the hyphae, which appear to enter into or extend from wc1, do not actually merge with wc1, but rather extend along the outer circumference of the spore. Unfortunately, the latter is impossible to determine due to the opaqueness of the spores and overall poor preservation of the fossil. (3) Alternatively, the hyphae might have been produced by the spores themselves such as in modern Glomus corymbiforme Błaszk. 
(Błaszkowski 1995), or (4) represent a type of interspore mycelium that is often found in complex spore-producing structures such as the sporocarps of Glomus badium Oehl, D. Redecker \& Sieverd. (Oehl et al. 2005, Błaszkowski 2012).

\section{Affinities of the fungus}

The systematic affinities of the fungal spores described in this study cannot be determined due to the lack of diagnostic features that can be used to directly compare the fossils to modern equivalents. Moreover, the fossils display a variety of morphological features that are reminiscent of extant members in several different lineages of fungi, including Ascomycota, Basidiomycota, and Mucoromycota (Mucoromycotina and Glomeromycotina). Phylogenetic studies indicate that these groups all were well established by Permian time (Blair 2009) and fossil evidence is generally supportive of these estimates (Taylor et al. 2015).

\section{Comparison with extant fungi}

Ascomycota. - Many members in the Ascomycota produce complex fruiting bodies, e.g., perithecia, apothecia, and cleistothecia (Spatafora et al. 2006, Sugiyama et al. 2006), but no evidence of such structures has been found in the fossil. However, species in the extant ascomycete genus Emericella (teleomorphs of Aspergillus) produce specialized, thick-walled cells (termed Hülle cells) terminally on specialized hyphae that surround the cleistothecia (Wu \& Miller 1997). Hülle cells are formed in masses and vary in shape between ovoid and globular in different species (Cvetkovic \& Vukic 1972, Ellis et al. 1973, Carvalho et al. 2002). The fossil spores are somewhat similar to Hülle cells, but differ in many ways. Hülle cells and the fossils share a prominent wall and are ellipsoidal to globose in shape; however, an average Hülle cell is $10-15 \mu \mathrm{m}$ in diameter (Bayram \& Braus 2012), while the fossil spores are up to $70 \mu \mathrm{m}$. Moreover, Hülle cells in general develop terminally on hyphae, and thus show only one attachment site, whereas some of the fossil spores clearly have two prominent canals, suggestive of intercalary development. However, figures 5 and 6 in Christensen et al. (1978) show Hülle cells with what appear to be multiple canals or hyphal attachment points. Finally, Hülle cells occur exclusively on cleistothecia, whereas the fossil fungus occurs in the form of a simple cluster of spores not surrounded by a complex ascocarp. On the other hand, the fossil spores are somewhat similar to the ascospores of certain extant ascomycetes. One of these forms is Corynascella humicola Arx \& Hodges, which produces thick-walled spores with two germ canals at opposite poles of the spore (Arx 1973, fig. 4c;
Malloch \& Cain 1973); however, no evidence of ascomata or asci is present in the fossil.

Basidiomycota. - The rust (Uredinales or Pucciniales) and smut (Ustilaginomycotina) fungi are obligate biotrophs and exclusively pathogenic on vascular plants, including lycophytes, ferns, gymnosperms, and most families of angiosperms (Begerow et al. 2014, Helfer 2014). They are present in all modern terrestrial ecosystems containing plants. Rust and smut fungi have complex life histories; they exploit living host plant tissues in order to complete their life cycles, but can survive unfavorable conditions in dead host tissue through resting spores (teliospores). Moreover, rust and smut fungi can physically alter their plant hosts through the formation of galls (Uchida et al. 2003). There is considerable morphological variation in the spore types, especially teliospores, of rusts and smuts (Cummins \& Hiratsuka 1984); for example, thick-walled rust teliospores can have germ pores (Uromyces sp.) and are produced in an intercalary manner (Pucciniosira sp.) (Oberwinkler 1982, 1993), features that morphologically resemble the fossil spores. Additionally, teliospores of some rust fungi such as Puccinia spp. are 45.9-52.1 $\mu \mathrm{m}$ in diameter (Anikster et al. 2005), which fits within the size range of the fossil spores that average $52 \mu \mathrm{m}$ in diameter. On the other hand, smut teliospores are on average $<25 \mu \mathrm{m}$ in diameter (e.g., Khanna et al. 1966), with only a few exceptions such as Tilletia paradoxa Jacz., with spores up to $50 \mu \mathrm{m}$ in diameter (Piepenbring et al. 1998). Prominent ornaments characterize the walls of rust and smut teliospores, often in the form of squat pyramidal structures that function as hooks to interlock the spores during development (Piepenbring et al. 1998, Helfer 2014). The fossil spores have columns in wc2 (Fig. 2J-L) that might be analogous to ornaments, but likely did not function as interlocking hooks. Although some rust and smut fungi can physically alter their hosts through the formation of galls, which does superficially resemble the degraded fossil host structure, we have not found any other structures characteristic of rust or smut fungi such as telia, pedicels, or sterile cells within the cluster of fossil spores (Piepenbring et al. 1998, Anikster et al. 2005, Helfer 2014).

Mucoromycota. - The fossil spores are morphologically similar in size (i.e., 50-70 $\mu \mathrm{m}$ in diameter), overall shape, and wall thickness to the zygospores of Endogone pseudopisiformis Y.J. Yao (Yao et al. 1995, pl. 7, fig. 63). Another Endogone species that produces thick-walled zygospores is Endogone aggregata P.A. Tandy (Tandy 1975, fig. 4). A structural feature that can be used to positively identify fossil Mucoromycotina is the presence of specialized gametangial hyphae to form a zygospore (zygosporogenesis) within a zygosporangium, i.e., gametangial fusion (O’Donnell 1979, Krings \& Taylor 2012). This feature has 
not been reported in members of the Glomeromycotina (Croll \& Sanders 2009, Schüßler \& Walker 2011). As a result, the presence of gametangia in organic connection can be accepted as proof that the affinities of a fossil lie with the Mucoromycotina, whereas the absence of gametangia cannot automatically be viewed as evidence in support of glomeromycotinan affinities (Krings \& Taylor 2013). The fossil spores described in this study lack specialized gametangial hyphae and therefore cannot be directly assigned to Mucoromycotina.

The fossil spores also resemble the spores of the enigmatic Gigaspora lazzarii Montecchi, Ruini \& G. Gross, a fungus that is formally included in the Glomeromycotina (Montecchi et al. 1996), but that, according to Schüßler \& Walker (2010), does in fact not share any features with any taxon in the Glomeromycotina, and thus remains unresolved with regard to systematic position. Gigaspora lazzarii produces spores in tightly adpressed clusters (> 20 spores) sheathed by a mucilaginous gleba, all within complex structures termed sporocarps. The spores are spherical to kidney shaped, 40-50 $\mu \mathrm{m}$ in diameter, and have three wall components. Gigaspora lazzarii, as well as the Endogone species previously discussed, produces spores within sporocarps, a key feature not unequivocally demonstrable in the fossil. However, the ill-preserved zone containing wide hyphae that surrounds the spore cluster (Fig. 2A-E) might perhaps be viewed as a peridium and, accordingly, the entire structure as a sporocarp that developed within the confines of a degrading plant part.

Many present-day glomoid species produce thickwalled spores that are similar in size to the fossils, including (thickest spore wall width given in parentheses) Funneliformis geosporum T.H. Nicolson et Gerd., which is approximately $175 \mu \mathrm{m}$ in diameter and produces 3 wall components $(9.5 \mu \mathrm{m})$; the outer hyaline wall component sloughs off leaving a granular surface (Walker 1982, Roesti et al. 2005). Claroideoglomus lamellosum Dalpé, Koske \& Tews is $100 \mu \mathrm{m}$ in diameter and also produces 3 wall components $(5.3 \mu \mathrm{m})$; the spore produces a pore that is $4.7 \mu \mathrm{m}$ in diameter and occluded by spore wall component 3 (Dalpé et al. 1992). Glomus hoi S.M. Berch \& Trappe is on average $92 \mu \mathrm{m}$ in diameter and also produces three wall components $(2.2 \mu \mathrm{m})$; pores are $5.1 \mu \mathrm{m}$ in diameter and occluded by a septum (Berch \& Trappe 1985). Funneliformis geosporum, C. lamellosum, and G. hoi all have three-layered walls, but are much larger than the fossil spores. Modern glomoid spores that are similar in diameter, but that do not have the same number of wall components as the fossil spores, include Diversispora insculpta Błaszk., which is approximately $60 \mu \mathrm{m}$ in diameter and only has 2 wall components (Błaszkowski et al. 2004), and Dominikia aurea Oehl \& Sieverd., which attains 55-65 $\mu \mathrm{m}$ in diameter and also has only 2 wall components (Oehl et al. 2003). Finally, it is interesting to note

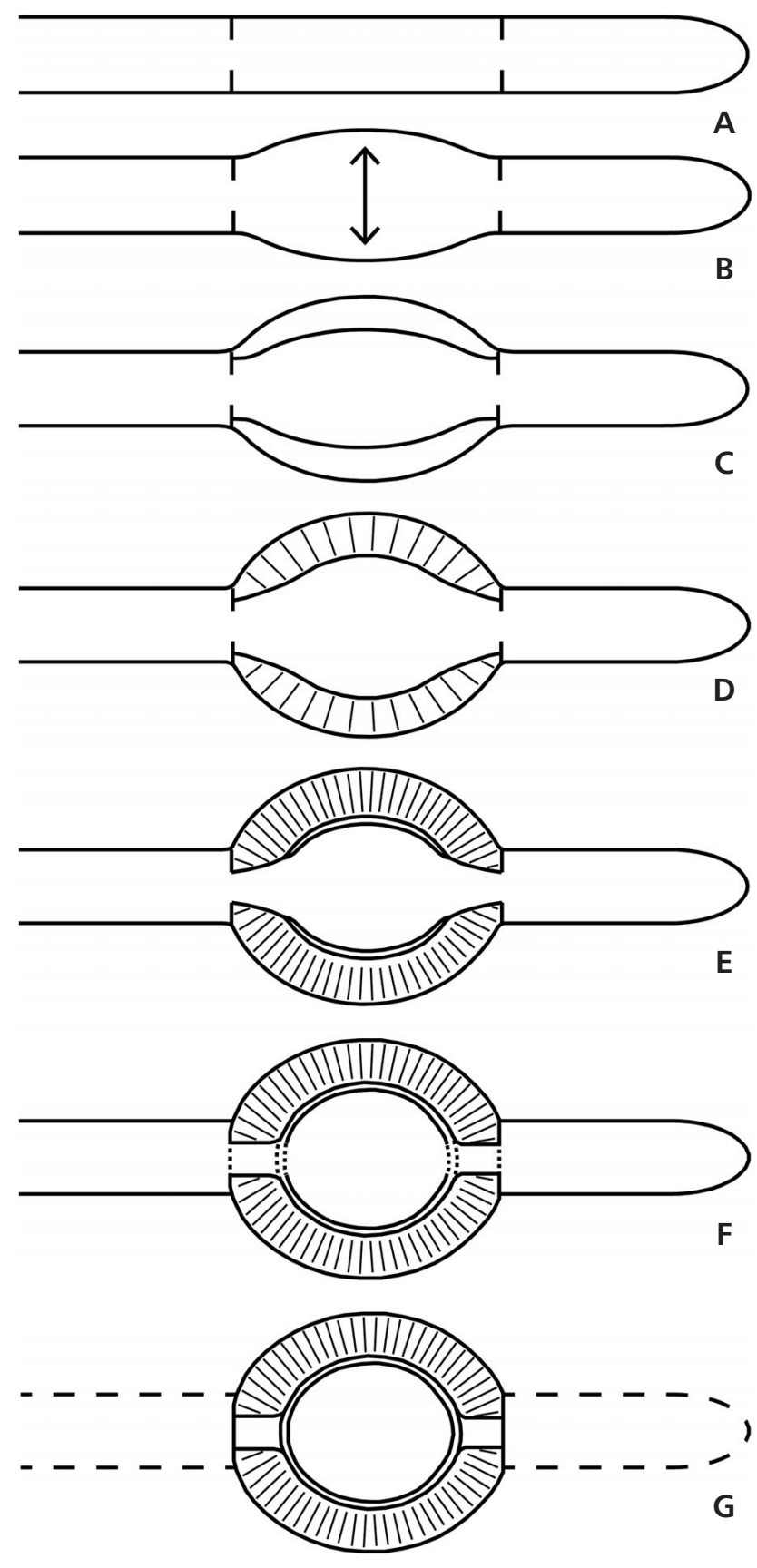

Figure 4. Fungal spore development. $\bullet A-G-$ hypothetical sequence of intercalary spore development (see detailed description in Discussion section - Fungal spore development).

that several extant Glomeromycotina produce spores with ornamented wall layers characterized by spines or other types of protuberances. For example, the spores of Acaulospora spinosa C. Walker \& Trappe (Walker \& Trappe 1981) are characterized by columnar- or spine-like projections extending from one of the wall components into another in a very similar pattern as that seen in wc 2 of the fossil spores (Fig. 2J, K). This feature has also been documented in a fossil putative 
glomeromycotinan spore from the Lower Devonian Rhynie chert (Krings et al. 2017).

\section{Permian thick-walled fungal spores from Antarctica}

Clusters of thick-walled spores occurring in highly degraded plant tissue (likely Vertebraria) have been described previously from the Skaar Ridge locality. The spores have been interpreted as terminal and intercalary glomeromycotinan chlamydospores and formally described as Glomorphites intercalaris García Mass. (García Massini 2007). The affinities of $G$. intercalaris to the Glomeromycotina were suggested based on morphological similarities to extant Glomus. Spores are $\sim 40 \mu \mathrm{m}$ in diameter and have three spore wall components, the thickest of which is $5 \mu \mathrm{m}$ wide. There are up to four subtending hyphal attachment points (4-9 $\mu \mathrm{m}$ in diameter) on each spore. The attachment points are characterized by a thickened rim or collar with suggested septa at the base. The thick-walled spores described in this study also possess three wall components, but are larger than G. intercalaris. Moreover, the wall components are structurally different from the components seen in G. intercalaris. There is no clear indication of subtending hyphal attachment points in the spores described in this study, but rather they are embedded in a confluent mycelium or tenuous hyphae, which appear to enter into or extend from the outermost spore wall component (wc1).

Other thick-walled fungal spores that come from the Toploje Member peat of the Bainmedart Coal Measures, Prince Charles Mountains, East Antarctica, are up to $20 \mu \mathrm{m}$ in diameter and possess a spore wall $\sim 2 \mu \mathrm{m}$ thick (Holdgate et al. 2005, fig. 14j). The spores are characterized by a polygonal surface pattern, and by prominent attachment points to the parental hypha. Moreover, Slater et al. (2015, fig. 6d) describe thick-walled spores of unknown affinities from within plant tissue that are $54 \mu \mathrm{m}$ in diameter and possess a wall up to $5.3 \mu \mathrm{m}$ thick. Many of these spores show prominent hyphal attachments $(1-3 \mu \mathrm{m}$ in diameter) with pronounced rims $\sim 11 \mu \mathrm{m}$ in diameter. In the same study, Slater et al. (2015, fig. 6e) also illustrate larger, thick-walled spores (i.e., up to $64 \mu \mathrm{m}$ in diameter) that possess a wall $9.3 \mu \mathrm{m}$ thick and a polygonal surface pattern. Most of these spores are produced terminally on hyphae $8.8-9 \mu \mathrm{m}$ in diameter; they occur in the matrix in close proximity to Vertebraria roots. The thick-walled spores described in this study differ from those described by Slater et al. (2015) with regard to size, mode of attachment to a parental hypha, and because they do not possess a polygonal surface pattern. However, we cannot rule out the possibility that the thick-walled spores described by Slater et al. (2015) represent a taphonomic and/or ontogenetic continuum of the same organism that produced the spores detailed in this study.

\section{Nature of the plant-fungus relationship}

The majority of fungal fossils preserved in the Permian Skaar Ridge permineralized peat are fragmented and dispersed, and do therefore not provide insights into fungal associations and interactions. The mass of fungal spores embedded in mycelium provides a rare opportunity to speculate on the relationship between a Permian fungus and its plant host. The large number of spores that occur densely clustered and surrounded by a confluent mycelium within a well-defined region of the host structure is suggestive of sporulation within the confines of the host (Dahlberg \& Van Etten 1982), rather than spores and mycelium being washed into the degrading plant part. Support for sporulation within the host is the dark zone containing wide hyphae that envelops the spore cluster. If the hypothesis that this structure represents a gall induced by a rust- or smut-like fungus is correct, then the fungus required the (telial) host plant for sporulation to produce resting spores (teliospores). An alternative hypothesis is that the structure represents a peridium produced by a fungus that formed sporocarps within plants, perhaps in a manner similar to certain extinct Mucoromycota, including Glomites sporocarpoides Karatygin, Snigirevskaya, K. Demchenko \& Zdebska from the Lower Devonian Rhynie chert (Karatygin et al. 2006). We are not aware of any modern mucoromycotan fungi that produce sporocarps within plant tissue exclusively when those plant remains are incorporated into the soil. Karatygin et al. (2006) suggested that, in the absence of nutrient-rich or well-established soils, G. sporocarpoides formed sporocarps within degrading plant parts; this may also be a plausible explanation for sporocarp formation in peat environments. The fungus in this study perhaps required a plant host in order to grow and eventually sporulate. Many modern fungi target plant reproductive structures due to their high concentration of nutritive tissues and function as parasites or require a specific plant host to complete their life cycles (e.g., Banerji 1962, Barrows-Broaddus \& Dwinell 1985, Clay 1991, Santini et al. 2008). However, the high degree of degradation prohibits determination of the precise nutritional mode of the fungus and whether the host was alive or dead at the time of fungal colonization. It is also possible that the fungus accidentally grew into or utilized the space provided by the degrading plant part lying on the forest floor or in the peat; or within a cavity excavated by a detritivore/herbivore. It is conceivable that sporulation was positively affected either by the confined space provided by the plant structure or the fungus had degraded the contents and left a void. It is interesting to note that confined spaces are known to positively affect sporulation in several modern members in the Glomeromycotina (Suwanarit et al. 1985, Rabatin \& Rhodes 1982, Koske \& Gemma 1995); similar behavior has also been suggested to occur in Glomeromy- 
cotina from the Lower Devonian Rhynie chert (Krings et al. 2015).

\section{Conclusions}

Documented evidence of fungal fossils from the Permian of Antarctica has previously been limited to detached, morphologically simple structures. This contribution provides an additional example of fungi occurring within Permian vascular plant (possibly glossopteridalean) parts. Moreover, the fossil described in this study suggests that the fungus sporulated within the confines of the host. We leave the systematic affinities of the fossil spores open, but suggest they do share certain features with modern chlamydospores that developed terminally or in an intercalary position. We hope that more complete and better-preserved specimens showing this type of plant-fungus association and fungal sporulation within plant remains become available as exploration of Antarctic permineralized peats continues, and that these specimens will reveal structural details that can be used to resolve the systematic affinities of the host, as well as the systematic affinities and nutritional mode of the fungus. As in modern ecosystems, different microorganisms colonized different plant structures utilizing a variety of strategies. A concerted investigation of the relationships between fossil fungi and specific host-plant organs represents a largely untapped area of research, but might be a potential means of more accurately characterizing microbial diversity in the late Paleozoic high-latitude peat-forming ecosystems of Antarctica.

\section{Acknowledgments}

We thank Dr. Patricia E. Ryberg (Parkville, MO, USA) for helpful discussion on glossopterid reproductive organs and Stefan Sónyi (Munich, Germany) for technical assistance. Financial support was provided by the Alexander von Humboldt-Foundation (3.1-USA/1160852 STP to CJH) and the National Science Foundation (EAR-0949947, and DEB-1441604 subcontract S1696A-A to MK; OPP-0943934 to ELT). The paper benefited from the constructive comments and suggestions of Ben J. Slater (Uppsala, Sweden) and an anonymous referee.

\section{References}

Anikster, Y., Eilam, T., Bushnell, W.R. \& Kosman, E. 2005. Spore dimensions of Puccinia species of cereal hosts as determined by image analysis. Mycologia 97, 474-484. DOI 10.1080/15572536.2006.11832823

ARX, J.A. von 1973. Ostiolate and non-ostiolate Pyrenomycetes. Proceedings of the Koninklijke Nederlandse Akademie van Wetenschappen. Series C. Biological and Medical sciences 76, 289-296.
BANERJI, M.L. 1962. An unreported fungus on Lycopodium annotinum L. Bulletin of the Botanical Society of Bengal 16, 45-46.

Barrett, P.J., Elliot, D.H. \& Lindsay, J.F. 1986. The Beacon Supergroup (Devonian-Triassic) and Ferrar Group (Jurassic) in the Beardmore Glacier area, Antarctica, 339-428. In Turner, M.D. \& Splettstoesser, J.F. (eds) Geology of the Central Transantarctic Mountains. American Geophysical Union, Antarctic Research S 36.

Barrows-Broaddus, J. \& Dwinell, L.D. 1985. Branch dieback and cone and seed infection caused by Fusarium moniliforme var. subglutinans in a loblolly pine seed orchard in South Carolina. Phytopathology 75, 1104-1108.

DOI 10.1094/Phyto-75-1104

BAYRAm, Ö. \& BRAUS, G.H. 2012. Coordination of secondary metabolism and development in fungi: the velvet family of regulatory proteins. FEMS Microbiology Reviews 36, 1-24. DOI 10.1111/j.1574-6976.2011.00285.x

Begerow, D., SchäFer, A.M., Kellner, R., Yurkov, A., Kemler, M., OBERWinkLer, F. \& BAUER, R. 2014. Ustilaginomycotina, 295-329. In McLaughlin, D.J. \& Spatafora, J.W. (eds) The Mycota VII Part A, Systematics and Evolution, 2nd Edition. Springer-Verlag, Berlin \& Heidelberg.

BerCh, S.M. \& TRAPPE, J.M. 1985. A new species of Endogonaceae, Glomus hoi. Mycologia 77, 645-657. DOI $10.2307 / 3793364$

Blair, J.E. 2009. Fungi, 215-219. In Hedges, S.B. \& Kumar, S. (eds) The timetree of life. Oxford University Press, New York, NY.

BŁAszKowski, J. 1995. Glomus corymbiforme, a new species in Glomales from Poland. Mycologia 87, 732-737. DOI $10.2307 / 3760819$

BŁaszKowski, J. 2012. Glomeromycota. 303 pp. W. Szafer Institute of Botany, Polish Academy of Sciences, Kraków.

BŁaszkowski, J., Adamska, I. \& Czerniawska, B. 2004. Glomus insculptum, a new arbuscular mycorrhizal species from Poland. Mycotaxon 89, 225-234.

Carvalho, M.D.F., Baracho, M.S. \& Baracho, I.R. 2002. Investigation of the nuclei of Hülle cells of Aspergillus nidulans. Genetic Molecular Biology 25, 485-488. DOI 10.1590/S1415-47572002000400019

Christensen, M., Raper, K.B. \& States, J.S. 1978. Two new Aspergillus nidulans group members from Wyoming soils. Mycologia 70, 332-342. DOI 10.2307/3759031

Clay, K. 1991. Parasitic castration of plants by fungi. Trends in Ecology and Evolution 6, 162-166. DOI 10.1016/0169-5347(91)90058-6

Collinson, J.W., Hammer, W.R., Askin, R.A. \& Elliot, D.H. 2006. Permian-Triassic boundary in the central Transantarctic Mountains, Antarctica. Geological Society of America Bulletin 118, 747-763. DOI 10.1130/B25739.1

Collinson, J.W., Isbell, J.L., Elliot, D.H., Miller, M.F. \& MilLER, J.M.G. 1994. Permian-Triassic Transantarctic Basin, 173-222. In Veevers, J.J. \& Powell, C.M.A. (eds) PermianTriassic Pangean Basins and Foldbelts along the Panthalassan Margin of Gondwanaland. Geological Society of America Memoirs 184.

Croll, D. \& Sanders, I.R. 2009. Recombination in Glomus intraradices, a supposed ancient asexual arbuscular mycorrhizal fungus. BMC Evolutionary Biology 9, 13. DOI 10.1186/1471-2148-9-13.

Cummins, G.B. \& HiRatsuka, Y. 1984. Families of Uredinales. 
Reports of the Tottori Mycological Institute (Japan) 22, 191-208.

Cúneo, N.R., IsBell, J.L., TAYLoR, E.L. \& TAYloR, T.N. 1993. The Glossopteris flora from Antarctica: Taphonomy and paleoecology, 13-40. In Archangelsky, S. (ed.) 12 Congrès International de Géologie du Carbonifère-Permian, Buenos Aires, Compte Rendu, Vol. 2.

Cvetkovic, M.M. \& Vukic, V.V. 1972. Influence of light on Hülle cell and aleuriospore formation in Aspergillus. Transactions of the British Mycological Society 58, 67-72. DOI 10.1016/S0007-1536(72)80072-X

DAhlBerG, K.R. \& VAn EtTen, J.L. 1982. Physiology and biochemistry of fungal sporulation. Annual Review of Phytopathology 20, 281-301. DOI 10.1146/annurev.py.20.090182.001433

Dalpé, Y., Koske, R.E. \& Tews, L.L. 1992. Glomus lamellosum sp. nov.: a new Glomaceae associated with beach grass. Mycotaxon 43, 289-293.

Decombeix, A.L., TAylor, E.L. \& TAYLOR, T.N. 2009. Secondary growth in Vertebraria roots from the Late Permian of Antarctica: A change in developmental timing. International Journal of Plant Sciences 170, 644-656. DOI 10.1086/597784

Decombeix, A.L., TAYlor, E.L. \& TAYLOR, T.N. 2010. Epicormic shoots in a Permian gymnosperm from Antarctica. International Journal of Plant Sciences 171, 772-782.

DOI $10.1086 / 654849$

Eldis, T.T., Reynolds, D.R. \& Alexopoulos, C.J. 1973. Hülle cells development in Emericella nidulans. Mycologia 65, 1029-1035. DOI 10.2307/3758285

FarabeE, M.J., TAYlor, E.L. \& TAYlor, T.N. 1990. Correlation of Permian and Triassic palynomorph assemblages from the central Transantarctic Mountains, Antarctica. Review of Palaeobotany and Palynology 65, 257-265.

DOI 10.1016/0034-6667(90)90075-T

FarabeE, M.J., TAYlor, E.L. \& TAYlOR, T.N. 1991. Late Permian palynomorphs from the Buckley Formation, central Transantarctic Mountains, Antarctica. Review of Palaeobotany and Palynology 69, 353-368.

DOI 10.1016/0034-6667(91)90037-4

Galtier, J. \& Phillips, T.L. 1999. The acetate peel technique, 67-70. In Jones, T.P. \& Rowe, N.P. (eds) Fossil Plants and Spores: Modern Techniques. The Geological Society, London.

Galtier, J. \& TAYlor, T.N. 1994. The first record of ferns from the Permian of Antarctica. Review of Palaeobotany and Palynology 83, 227-239.

DOI 10.1016/0034-6667(94)90071-X

García Massini, J. 2007. A glomalean fungus from the Permian of Antarctica. International Journal of Plant Sciences 168, 673-678. DOI 10.1086/513478

Harper, C.J., Decombeix, A.L., Taylor, E.L., Taylor, T.N. \& KRINGS, M. 2017a. Fungal decay in Permian glossopteridalean stem and root wood from Antarctica. IAWA Journal 38, 29-48. DOI 10.1163/22941932-20170155

Harper, C.J., Krings, M., Dotzler, N., TAylor, E.L. \& TAYlor, T.N. 2017b. Deciphering interfungal relationships in the 410-million-yr-old Rhynie chert: Morphology and development of vesicle-colonizing microfungi. Geobios 50, 9-22. DOI 10.1016/j.geobios.2016.11.003

Harper, C.J., TAYlor, T.N., Krings, M. \& TAYlor, E.L. 2013. Mycorrhizal symbiosis in the Paleozoic seed fern Glossopteris from Antarctica. Review of Palaeobotany and Palynology 192, 22-31. DOI 10.1016/j.revpalbo.2013.01.002
Harper, C.J., TAylor, T.N., Krings, M. \& TAYlor, E.L. 2015. Fungi associated with Glossopteris (Glossopteridales) leaves from the Permian of Antarctica: A preliminary report. Zitteliana A 55, 107-114.

Harper, C.J., Taylor, T.N., Krings, M. \& TAylor, E.L. 2016. Structurally preserved fungi from Antarctica: Diversity and interactions in late Palaeozoic and Mesozoic polar forest ecosystems. Antarctic Science 28, 153-173. DOI 10.1017/S0954102016000018

HeLFer, S. 2014. Rust fungi and global change. New Phytologist 201, 770-780. DOI 10.1111/nph.12570

Holdgate, G.R., Mcloughlin, S., Drinnan, A.N., Finkelman, R.B., Willett, J.C. \& Chiehowsky, L.A. 2005. Inorganic chemistry, petrography and palaeobotany of Permian coals in the Prince Charles Mountains, East Antarctica. International Journal of Coal Geology 63, 156-177. DOI 10.1016/j.coal.2005.02.011

IsBeLL, J.L. 1990. Fluvial sedimentology and basin analysis of the Permian Fairchild and Buckley Formations, Beardmore Glacier region, and the Weller Coal Measures, Southern Victoria Land, Antarctica. 388 pp. Ph.D. thesis, The Ohio State University, Columbus, USA.

Joy, K.W., WiLlis, A.J. \& LaCeY, W.S. 1956. A rapid cellulose peel technique in palaeobotany. Annals of Botany 20, 635-637. DOI 10.1093/oxfordjournals.aob.a083546

Karatygin, I.V., Snigirevskaya, N.S. \& Demchenko, K.N. 2006. Species of the genus Glomites as plant mycobionts in Early Devonian ecosystems. Paleontological Journal 40, 572-579. DOI 10.1134/S0031030106050121

Kettunen, E., Grabenhorst, H., Gröhn, C., Dörfelt, H., Sadowski, E.M., Rikkinen, J. \& Schmidt, A.R. 2015. The enigmatic hyphomycete Torula sensu Caspary revisited. Review of Palaeobotany and Palynology 219, 183-193. DOI 10.1016/j.revpalbo.2015.03.010

Khanna, A., Payak, M.M. \& Mehta, S.C. 1966. Teliospore morphology of some smut fungi. I. Electron microscopy. Mycologia 58, 562-569. DOI 10.2307/3757035

Klavins, S.D., TAylor, E.L., Krings, M. \& TAYlor, T.N. 2001. An unusual, structurally preserved ovule from the Permian of Antarctica. Review of Palaeobotany and Palynology 115, 107-117. DOI 10.1016/S0034-6667(01)00052-5

Koske, R.E. \& Gemma, J.N. 1995. Scutellospora hawaiiensis: A new species of arbuscular mycorrhizal fungus from Hawaii. Mycologia 87, 678-683. DOI 10.2307/3760811

Krings, M. \& TAYLOR, T.N. 2012. Fungal reproductive units enveloped in a hyphal mantle from the Lower Pennsylvanian of Great Britain, and their relevance to our understanding of Carboniferous fungal "sporocarps." Review of Palaeobotany and Palynology 175, 1-9. DOI 10.1016/j.revpalbo.2012.03.001

Krings, M. \& TAYLOR, T.N. 2013. Zwergimyces vestitus (Kidston et WH Lang) nov. comb., a fungal reproductive unit enveloped in a hyphal mantle from the Lower Devonian Rhynie chert. Review of Palaeobotany and Palynology 190, 15-19. DOI 10.1016/j.revpalbo.2012.11.008

Krings, M. \& TAYLOR, T.N. 2015. Mantled fungal reproductive units in land plant tissue from the Lower Devonian Rhynie chert. Bulletin of Geosciences 90, 1-6.

DOI 10.3140/bull.geosci.1519

Krings, M., Taylor, T.N., DotZler, N. \& Harper, C.J. 2016. Morphology and ontogenetic development of Zwergimyces vestitus, a fungal reproductive unit enveloped in a hyphal mantle from the Lower Devonian Rhynie chert. Review of 
Palaeobotany and Palynology 228, 47-56.

DOI 10.1016/j.revpalbo.2016.01.005

Krings, M., Taylor, T.N., Kerp, H., Walker, C. 2015. Deciphering interfungal relationships in the 410-million-yr-old Rhynie chert: Sporocarp formation in glomeromycotan spores. Geobios 48, 449-458. DOI 10.1016/j.geobios.2015.09.003

Krings, M., Walker, C., Harper, C.J., Martin, H., Sónyi, S., KustatsChER, E. \& TAYLOR, T.N. 2017. Unusual fungal reproductive units from the Lower Devonian Rhynie chert. Zitteliana A 89, 29-37.

KyLE, R.A. 1974. Plumsteadia ovata n. sp., a glossopterid fructification from South Victoria Land, Antarctica. New Zealand Journal of Geology and Geophysics 17, 719-721. DOI 10.1080/00288306.1973.10421590

Lambrecht, L.L., LaCeY, W.S. \& SMith, C.S. 1972. Observations on the Permian flora of the Law Glacier area, central Transantarctic Mountains. Bulletin de la Société Belge de Géologie, de Paléontologie et d'Hydrologie 81, 161-167.

Malloch, D. \& CAIN, R.F. 1973. The genus Thielavia. Mycologia 65, 1055-1077. DOI 10.2307/3758288

Mantle, D.J., Kelman, A.P., Nicoll, R.S. \& Laurie, J.R. 2010. Australian Biozonation Chart. 1 p. Geoscience Australia, Canberra.

McLoughlin, S. \& Drinnan, A.N. 1996. Anatomically preserved Permian Noeggerathiopsis leaves from East Antarctica. Review of Palaeobotany and Palynology 92, 207-227. DOI 10.1016/0034-6667(96)00134-0

Mcloughlin, S., Drinnan, A.N., Slater, B.J. \& Hilton, J. 2015. Paurodendron stellatum: A new Permian permineralized herbaceous lycopsid from the Prince Charles Mountains, Antarctica. Review of Palaeobotany and Palynology 220, 1-15. DOI 10.1016/j.revpalbo.2015.04.004

McLoughlin, S., Lindström, S. \& Drinnan, A.N. 1997. Gondwanan floristic and sedimentological trends during the Permian-Triassic transition: New evidence from the Amery Group, northern Prince Charles Mountains, East Antarctica. Antarctic Science 9, 281-298.

DOI $10.1017 /$ S0954102097000370

Mcloughlin, S., Slater, B., Hilton, J. \& Prevec, R. 2011. New vistas on animal-plant-fungal interactions in the PermianTriassic of Gondwana. GFF 133, 66-67.

Montecchi, A., Ruini, S. \& Gross, G. 1996. Gigaspora lazzarii nov. sp. Rivista di Micologia 39, 21-28.

Moore, R.T. \& McAlear, J.H. 1962. Fine structure of mycota. 7. Observations on septa of Ascomycetes and Basidiomycetes. American Journal of Botany 49, 86-94. DOI $10.2307 / 2439393$

Ngugi, H.K. \& Scherm, H. 2006. Biology of flower-infecting fungi. Annual Review of Phytopathology 44, 261-282. DOI 10.1146/annurev.phyto.44.070505.143405

OBERWINKLER, F. 1982. The significance of the morphology of the basidium in the phylogeny of basidiomycetes, 9-35. In WeLLS, K. \& Wells, E.K. (eds) Basidium and Basidiocarp. Springer, Berlin, Heidelberg \& New York.

OBerWinkLeR, F. 1993. Diversity and phylogenetic importance of tropical heterobasidiomycetes, 121-147. In IsAAC, S., Frankland, J.C., Watling, R. \& Whalley, A.J.S. (eds) Aspects of Tropical Mycology. Cambridge University Press, Cambridge.

O'donnell, K. 1979. Zygomycetes in Culture. Palfrey Contributions in Botany. No. 2. 257 pp. Department of Botany, University of Georgia, Athens.
Oehl, F., Redecker, D. \& Sieverding, E. 2005. Glomus badium, a new sporocarpic mycorrhizal fungal species from European grasslands with higher soil $\mathrm{pH}$. Journal of Applied Botany and Food Quality 79, 38-43.

Oehl, F., Wiemken, A. \& Sieverding, E. 2003. Glomus aureum, a new sporocarpic arbuscular mycorrhizal fungal species from European grasslands. Journal of Applied Botany 77, 111-115.

Piepenbring, M., Bauer, R. \& Oberwinkler, F. 1998. Teliospores of smut fungi. General aspects of teliospore walls and sporogenesis. Protoplasma 204, 155-169. DOI 10.1007/BF01280322

Price, P.L., Filatoff, J., Williams, A.J., Pickering, S.A. \& Wood, G.R. 1985. Late Palaeozoic and Mesozoic palynostratigraphic units, 1-20. In Queensland Department of Resource Industries Open File Report, CR14012. CSR Oil and Gas Division Palynology Facility Report 274/25.

RABATIN, S.C. \& RHODES, L.H. 1982. Acaulospora bireticulata inside oribatid mites. Mycologia 74, 859-861. DOI $10.2307 / 3792878$

Retallack, G.J., Jahren, A.H., Sheldon, N.D., Chakrabarti, R., Metzger, C.A. \& Smith, R.M.H. 2005. The Permian-Triassic boundary in Antarctica. Antarctic Science 17, 241-258. DOI 10.1017/S0954102005002658

RibGy, J.F., Kwiecien, W. \& WhiteheAd, R.E. 2001. The geochemistry and palaeobotany of a Permian lake in Prince Charles Mountains, Antarctica, 409-419. In WeIss, R.H. (ed.) Contributions to Geology and Palaeontology of Gondwana in Honour of Helmut Wopfner. University of Cologne Geological Institute, Cologne.

Roesti, D., Ineichen, K., Braissant, O., Redecker, D., Wiemken, A. \& ARAGno, M. 2005. Bacteria associated with spores of the arbuscular mycorrhizal fungi Glomus geosporum and Glomus constrictum. Applied Environmental Microbiology 71, 6673-6679. DOI 10.1128/AEM.71.11.6673-6679.2005

RYBERG, P.E. 2009. Reproductive diversity of Antarctic glossopterid seed-ferns. Review of Palaeobotany and Palynology 158, 167-179. DOI 10.1016/j.revpalbo.2009.08.006

RyberG, P.E. 2010. Lakkosia kerasata gen. et sp. nov., a permineralized megasporangiate glossopterid structure from the central Transantarctic Mountains, Antarctica. International Journal of Plant Sciences 171, 332-344.

DOI 10.1086/650156

RYBERG, P.E. \& TAYLOR, E.L. 2013. Lonchiphyllum aplospermum gen. et sp. nov.: An anatomically preserved glossopterid megasporophyll from the Upper Permian of Skaar Ridge, Transantarctic Mountains, Antarctica. International Journal of Plant Sciences 174, 396-405. DOI 10.1086/668222

Ryberg, P.E., TAylor, E.L. \& TAylor, T.N. 2012a. The first permineralized microsporophyll of the Glossopteridales: Eretmonia macloughlinii sp. nov. International Journal of Plant Sciences 173, 812-822. DOI 10.1086/666667

Ryberg, P.E., TAYlor, E.L. \& TAYlor, T.N. $2012 \mathrm{~b}$. Permineralized lycopsid from the Permian of Antarctica. Review of Palaeobotany and Palynology 169, 1-6. DOI 10.1016/j.revpalbo.2011.10.001

Ryberg, P.E., TAYloR, E.L. \& TAYLOR, T.N. 2012c. Antarctic glossopterid diversity on a local scale: The presence of multiple megasporophyll genera, Upper Permian, Mt. Achernar, Transantarctic Mountains, Antarctica. American Journal of Botany 99, 1531-1540. DOI 10.3732/ajb.1200142

Santini, A., Pepori, A., Ghelardini, L. \& Capretti, P. 2008. Persistence of some pine pathogens in coarse woody debris and 
cones in a Pinus pinea forest. Forest Ecology and Management 256, 502-506. DOI 10.1016/j.foreco.2008.05.010

Schopf, J.M. 1970a. Petrified peat from a Permian coal bed in Antarctica. Science 169, 274-277.

DOI 10.1126/science.169.3942.274

SCHOPF, J.M. 1970b. Relation of floras of the Southern hemisphere to continental drift. Taxon 19, 657-674. DOI $10.2307 / 1219279$

SCHOPF, J.M. 1971. Notes on plant tissue preservation and mineralization in a Permian deposit of peat from Antarctica. American Journal of Science 271, 522-543. DOI 10.2475/ajs.271.5.522

SCHOPF, J.M. 1976. Morphological interpretation of fertile structures in glossopterid gymnosperms. Review of Palaeobotany and Palynology 21, 25-64. DOI 10.1016/0034-6667(76)90021-X

SCHÜßLER, A. \& WALKER, C. 2010. The Glomeromycota: a species list with new families and genera. The Royal Botanical Garden Edinburgh, The Royal Botanic Garden Kew, Botanische Staatssammlung Munich, and Oregon State University. http://amf-phylogeny.com

SCHÜßLER, A. \& WALKER, C. 2011. Evolution of the 'plant-symbiotic' fungal phylum, Glomeromycota, 163-185. In PöGGELER, S. \& Wöstemeyer, J. (eds) Evolution of Fungi and Fungal-Like Organisms. The Mycota XIV. Springer Verlag, Berlin Heidelberg.

Slater, B.J., McLoughlin, S. \& Hilton, J. 2011. Guadalupian (Middle Permian) megaspores from a permineralised peat in the Bainmedart Coal Measures, Prince Charles Mountains, Antarctica. Review of Palaeobotany and Palynology 167, 140-155. DOI 10.1016/j.revpalbo.2011.07.007

Slater, B.J., McLoughlin, S. \& Hilton, J. 2012. Animal-plant interactions in a Middle Permian permineralised peat of the Bainmedart Coal Measures, Prince Charles Mountains, Antarctica. Palaeogeography, Palaeoclimatology, Palaeoecology 363-364, 109-126. DOI 10.1016/j.palaeo.2012.08.018

Slater, B.J., McLoughlin, S. \& Hilton, J. 2015. A high-latitude Gondwanan Lagerstätte: The Permian permineralised peat biota of the Prince Charles Mountains, Antarctica. Gondwana Research 27, 1446-1473. DOI 10.1016/j.gr.2014.01.004

SмоOT, E.L. \& TAYLOR, T.N. 1986. Structurally preserved fossil plants from Antarctica: II. A Permian moss from the Transantarctic Mountains. American Journal of Botany 73, 1683-1691. DOI 10.2307/2444234

Spatafora, J.W., Johnson, D., Sung, G.H., Hosaka, K., O'rourke, B., Serdani, M., Spotts, R., Lutzoni, F., Hofstetter, V., Fraker, E., Gueidan, C., Miadlikowska, J., Reeb, V., Lumbsch, T., LÜCKInG, R., Schmitt, I., Aptroot, A., Roux, C., Miller, A., Geiser, D., Hafellner, J., Hestmark, G., Arnold, A.E., Büdel, B., Rauhut, A., Hewitt, D., Untereiner, W., Cole, M.S., Scheidegger, C., Schultz, M., Sipman, H. \& Schoch, C. 2006. A five-gene phylogenetic analysis of the Pezizomycotina. Mycologia 98, 1020-1030. DOI 10.1080/15572536.2006.11832630

Sugiyama, J., Hosaka, K. \& Suh, S.O. 2006. Early diverging Ascomycota: phylogenetic divergence and related evolutionary enigmas. Mycologia 98, 996-1005. DOI 10.1080/15572536.2006.11832628

Sumanarit, P., Chewatanaruk, R., Chantanao, A. \& SuWANAADTH, M. 1985. Species of fungi hyperparasitising on VA mycorrhizal fungi, 222-227. In Thailand National Corn and Sorghum Program 1985 Annual Report, Bangkok, Thailand.

TANDY, P.A. 1975. Sporocarpic species of Endogonaceae in Australia. Australian Journal of Botany 23, 849-866. DOI 10.1071/BT9750849

TAYLOR, T.N. \& TAYLOR, E.L. 1987. Structurally preserved fossil plants from Antarctica. III. Permian seeds. American Journal of Botany 74, 904-913. DOI 10.2307/2443871

TAYLOR, E.L. \& TAYLOR, T.N. 1992. Reproductive biology of the Permian Glossopteridales and their suggested relationship to flowering plants. Proceedings of the National Academy of Sciences of the United States of America 89, 11495-11497. DOI 10.1073/pnas.89.23.11495

TAYLOR, T.N., HASs, H. \& KeRP, H. 1997. A cyanolichen from the Lower Devonian Rhynie chert. American Journal of Botany 84, 992-1004. DOI 10.2307/2446290

TAYlor, T.N., Krings, M. \& TAYLOR, E.L. 2015. Fossil Fungi. 382 pp. Academic Press, London.

TAYlor, E.L., TAYlor, T.N. \& Collinson, J.W. 1989. Depositional setting and paleobotany of Permian and Triassic permineralized peat from the central Transantarctic Mountains, Antarctica. DOI 10.1016/0166-5162(89)90068-2

TAYLOR, E.L., TAYLOR, T.N. \& Ryberg, P.E. 2007. Ovule-bearing reproductive organs of the glossopterid seed ferns from the Late Permian of the Beardmore Glacier region, Antarctica. In Cooper, A.K. \& Raymond, C.R. (eds) Antarctica: A Keystone in a Changing World. Proceedings of the $10^{\text {th }}$ International Symposium on Antarctic Earth Sciences. US Geological Survey, Open-File Report 2007-1047, Short Research Paper 082. https://pubs.usgs.gov/of/2007/1047/srp/srp082/ DOI 10.3133/of2007-1047.srp082

Uchida, W., Matsunaga, S., Sugiyama, R., Kazama, Y. \& KaWAno, S. 2003. Morphological development of anthers induced by the dimorphic smut fungus Microbotryum violaceum in female flowers of the dioecious plant Silene latifolia. Planta 218, 240-248. DOI 10.1007/s00425-003-1110-8

Vujanovic, V., St-Arnaud, M. \& Neumann, P.J. 2000. Susceptibility of cones and seeds to fungal infection in a pine (Pinus spp.) collection. Forest Pathology 30, 305-320.

DOI 10.1046/j.1439-0329.2000.00211.x

WALKER, C. 1982. Species in the Endogonaceae: A new species (Glomus occultum) and a new combination (Glomus geosporum). Mycotaxon 15, 49-61.

WALKER, C. 1983. Taxonomic concepts in the Endogonaceae: spore wall characteristics in species descriptions. Mycotaxon $18,443-455$.

WAlker, C. \& TRAPPe, J.M. 1981. Acaulospora spinosa sp. nov. with a key to the species of Acaulospora. Mycotaxon 12, 515-521.

Weaver, L., McLoughlin, S. \& Drinnan, A.N. 1997. Fossil woods from the Upper Permian Bainmedart Coal Measures, northern Prince Charles Mountains, East Antarctica. AGSO Journal of Australian Geology and Geophysics 16, 655-676.

Wu, J. \& Miller, B.L. 1997. Aspergillus asexual reproduction and sexual reproduction are differentially affected by transcriptional and translational mechanisms regulating stunted gene expression. Molecular Cell Biology 17, 6191-6201. DOI 10.1128/MCB.17.10.6191

Yao, Y.J., Pegler, D.N. \& Young, T.W.K. 1995. New species in Endogone (Endogonales). Kew Bulletin 50, 359-365. DOI $10.2307 / 4110642$ 